\title{
PENGATURAN HUKUM CALON LEGISLATIF MANTAN NARAPIDANA
}

\author{
Oleh: \\ Salim Fauzi Lubis ${ }^{1)}$, \\ Ismail $^{2)}$, \\ dan Mina Mardiana ${ }^{3}$ \\ Universitas Asahan ${ }^{1,2,3)}$ \\ E-mail: \\ $\underline{\text { lubis_dojo@gmail.com }}{ }^{1)}$, \\ ismailizu@yahoo.com ${ }^{2)}$, \\ minamardiana410@ gmail.com $^{3)}$
}

\begin{abstract}
Election or local election is a way of channeling the rights of every principle community, which means that the right to vote and being voted is contained in his constitutional rights as citizens. In article 28 letter D of the Republic of Indonesia Republic of 1945 stating "every citizen has the right to have the same opportunity in government". This contains the understanding that the State guarantees each of its citizens to obtain the rights to sit in government either as People's Representatives, regents, Mayors, Governors, or even become a President. The method used in this study is normative juridical legal research using a statutory approach. The issue raised by the author is How the Human Rights Perspective of Legislative Candidates in Organizing Elections and How Comparative Legal Arrangements for Former Legislative Candidates Examined From Law Number 7 of 2017 Concerning General Elections With Regulation of the Election Commission Number 20 of 2018 Regarding Nominating Members Regional Representative Council, Provincial Regional Representative Council, Regency / City Representative Council. In terms of the implementation of elections need to be held honestly, fairly and democratically based on the spirit of Democracy that has been carried out so far to create leaders and representatives of the people who side with their people. Speaking of Human Rights, everyone has the same rights before the State and applies to former corruption convicts who have or have the same political rights as other citizens guaranteed by the constitution.
\end{abstract}

Keywords: Legislative Candidates, General Election, Former Prisoners.

ABSTRAK
Pemilu atau pemilihan lokal adalah cara menyalurkan hak-hak setiap komunitas prinsip, yang berarti bahwa hak untuk memilih dan dipilih terkandung dalam hak konstitusionalnya sebagai warga negara. Dalam pasal 28 huruf D Republik Indonesia Republik 1945 menyatakan "setiap warga negara memiliki hak untuk memiliki kesempatan yang sama dalam pemerintahan". Ini berisi pemahaman bahwa Negara menjamin setiap warganya untuk memperoleh hak untuk duduk dalam pemerintahan baik sebagai Perwakilan Rakyat, bupati, Walikota, Gubernur, atau bahkan menjadi Presiden. Metode yang digunakan dalam penelitian ini adalah penelitian hukum yuridis normatif dengan menggunakan pendekatan statutory. Masalah yang diangkat oleh penulis adalah Bagaimana Perspektif Hak Asasi Manusia dari Calon Legislatif dalam Mengatur Pemilihan Umum dan Bagaimana Pengaturan Hukum Komparatif untuk Calon Legislatif Mantan Diperiksa Dari UndangUndang Nomor 7 Tahun 2017 Tentang Pemilihan Umum Dengan Peraturan Komisi Pemilihan Umum Nomor 20 Tahun 2018 Tentang Memberi Nominasi Anggota Dewan Perwakilan Daerah, Dewan Perwakilan Daerah Provinsi, Dewan Perwakilan Kabupaten / Kota. Dalam hal pelaksanaan pemilu perlu diadakan secara jujur, adil dan demokratis berdasarkan semangat Demokrasi yang telah dilakukan selama ini untuk menciptakan pemimpin dan perwakilan rakyat yang berpihak pada rakyatnya. Berbicara tentang Hak Asasi Manusia, setiap orang memiliki hak yang sama di hadapan Negara dan berlaku untuk mantan narapidana korupsi yang memiliki atau memiliki hak politik yang sama dengan warga negara lain yang dijamin oleh konstitusi.

Kata kunci: Calon Legislatif, Pemilihan Umum, Mantan Tahanan. 


\section{PENDAHULUAN}

Sejak awal pemerintahan SBY dikenal adanya Pemilihan umum. Pemilihan umum merupakan salah satu yang diberlakukan di indonesia yang merupakan suatu sarana atau wadah dalam membentuk pemerintahan yang lebih demokratis melalui adanya mekanisme yang jujur dan adil pelaksanaannya (Ahmad Zazili, 2012 : 136). Dalam pasalnya yang ke 28 huruf D Undang-Undang Dasar Negara Republik Indonesia 1945 (UUD 1945) yang berbunyi mengenai bahwa "setiap orang berhak memperoleh kesempatan yang sama dalam pemerintahan". Maka berdasarkan dari bunyi pasal tersebut, mengenai adanya pemilu, setiap warga negara berhak untuk memilih dan dipilih yang dalam hal ini telah dijamin dalam UUD 1945.

Di Indonesia ada yang namanya Sistem Politik Demokrasi yang mana artinya dipilih karena hasil demokrasi yang memberikan posisi atau kedudukan yang penting bagi rakyat. Sebagai rakyat yang memiliki kekuasaan tertinggi dalam menentukan kebijakan Negara melalui wakil-wakil rakyat yang dipilih melalui pemilihan umum perlu adanya kehati-hatian dalam menentukan wakil dan pemimpinnya. Secara teorinya, teori demokrasi konstitusional di Indonesia tidak akan dapat lepas dari adanya konsep demokrasi dan nomokrasi, sebab kedua hal tersebut merupakan sesuatu yang saling berkonvergensi (menyamakan persepsi) maka telah memunculkan adanya konsep Negara hukum yang demokratis (democratische rechtsstaat) dan Negara demokrasi berdasarkan hukum (consstituonal democrate stat) yang memang keduanya saling berkaitan ataupun berhubungan (Bisarida dkk, 2012: 538)

Pemilihan umum (pemilu) adalah sebuah sarana kedaulatan rakyat dalam memilih anggota-anggota dewan perwakilan rakyat atau DPR, anggota perwakilan daerah atau DPD, presiden dan wakil presiden dan untuk memilih anggota dewan perwakilan rakyat daerah atau DPRD, yang proses pelaksanaan secara langsung pemilihannya, umum, bebas, rahasia, jujur, dan adil dalam kedaulatan NKRI berdasarkan yang tertuang dalam pasal 1 ayat (satu) Undang-Undang Nomor 7 tahun 2007 tentang Pemilihan Umum. Di dalam Pemilihan kepala daerah atau pemilukada itu merupakan suatu aktualisasi demokrasi daerah saat ini yang sejalan demgan Pemilu. Dalam pandangan secara filosofis, munculnya suatu ide mengenai pilkada secara langsung yang pada dasarnya merupakan suatu proses kelanjutan dari keinginan kuat dalam menciptakan dan memperbaiki kualitas demokrasi didaerah saat ini. Yang diharapkan dari pemilihan kepala daerah secara langsung adalah supaya dapat melahirkan pemimpin yang mampu dan didukung oleh rakyat dan memang peduli dengan rakyat. Pilkada yang dilakukan secara langsung juga diharapkan mampu menjadi suatu alat pergantian politik saat ini, dimana orang terbaik di daerah bisa menjadi pemimpin yang layak dan memang pantas menjadi pemimpin di daerahnya (Suharizal, 2010:95)

Sehingga dalam pelaksanaannya sendiri, pemilu haruslah mengacu pada beberapa standar untuk bisa dikatakan sebagai pemilu yang demokratis yaitu : a. sebuah standar acuan dalam mewujudkan suatu pemilu yang memang benar-benar demokratis yang artinya dalam segi pelaksanaan pemilu adalah harus memberikan suatu kesempatan kepada semua partai-partai politik untuk saling bersaing secara bebas, jujur, dan adil untuk menciptakan demokrasi itu sendiri. b. Untuk memilih wakil rakyat yang berkualitas, berintegritas moral dan mencerminkan kehendak rakyat harus benar adanya keinginan dari hati nurani rakyat. $c$. 
dalam pemilu haruslah melibatkan semua warga Negara tanpa terkecuali, supaya rakyat memang benar-benar mempunyai kepercayaan bahwa dirinya merupakan perwujudan dari kedaulatan rakyat dan jangan terjadi diskriminasi terhadap hak yang diperolehnya tersebut. d. pemilu dilaksakan berdasarkan peraturan yang mendukung adanya kebebasan dan kejujuran baik dalam segi pelaksanaannya maupun hasil yang diperoleh dari pemilu tersebut. e. pemilu haruslah mempertimbangkan instrument penyelenggranya, sebab sangat memungkinkan adanya kepentingankepentingan penyelenggara akan mengganggu kemurnian pemilu maka haruslah penyelenggaranya itu bersifat netral. f. pemilu berdasarkan pandangan filosofis, hendaknya lebih ditekankan pada manifestasi hak masyarakat untuk menciptakan partisipasi masyarakat dalam perintahan sehingga memang disini yang dibutuhkan partisipasi masyarakat banyak dan kesadaran mengenai pemilu itu sendiri (Bisarida all, 2012:538).

\section{Rumusan Masalah}

Berdasarkan latar belakang diatas maka rumusan maslah yang diangkat oleh penulis adalah sebagai berikut :

1. Bagaimana Perspektif Hak Asasi Manusia Calon Legislatif Dalam Penyelenggaraan Pemilu.

2. Bagaimana Komparasi Pengaturan Hukum Calon Legislatif Mantan Narapidana Ditinjau Dari UndangUndang Nomor 7 Tahun 2017 Tentang Pemilihan Umum Dengan Peraturan Komisi Pemilihan Umum Nomor 20 Tahun 2018 Tentang Pencalonan Anggota Dewan Perwakilan Daerah, Dewan Perwakilan Daerah Provinsi, Dewan Perwakilan Kabupaten/Kota.

\section{METODE PENELITIAN}

\subsection{Metode}

Metode yang digunakan dalam penulisan ini adalah metode penelitian secara yuridis-normatif dengan kedekatan terhadap asasasas hukum serta mengacu pada norma hukum yang terdapat dalam peraturan perundang - undangan, yang artinya bahwa menganalisis permasalahan hukum yang sedang diteliti dengan cara menelaah berbagai peraturan perundangundangan yang berhubungan dengan permasalahan hukum yang sedang diteliti ( Soerjono Soekanto dan Sri Mamudji, 1995 : 13 ).

\subsection{Sumber Bahan Hukum}

Sumber bahan hukum yang akan digunakan dalam penelitian ini adalah sumber bahan hukum primer, sekunder, tersier.

a. Bahan Hukum Primer, bahan hukum primer merupakan bahan yang menjadi patokan utama dan mengikat yaitu sebagai berikut :

1. Undang - Undang Dasar 1945

2. Undang - Undang Nomor 7 Tahuan $2017 \quad$ Tentang Pemilihan Umum.

3. Undang - Undang Nomor 20 Tahun 2018 Tentang Pencalonan Anggota Dewan Perwakilan Daerah, Dewan Perwakilan Daerah Provinsi, Dewan Perwakilan Kabupaten/ Kota.

b. Bahan Hukum Sekunder, bahan hukum sekunder yaitu bahan hukum yang dipergunakan berupa buku-buku yang berkaitan dengan pengaturan hukum calon legislatif mantan narapidana 
yang mendukung dari bahan hukum primer.

c. Bahan Hukum Tesier, bahan hukum tersier yaitu suatu bahan hukum yang memberikan petunjuk maupun penjelesan mengenai bahan hukum primer dan bahan hukum sekunder atau dalam arti lain adalah sebagai bahan penunjang kedua bahan sebelumnya contohnya adalah kamus ensklopedia.

\subsection{Prosedur Pengumpulan Bahan Hukum}

Prosedur pengumpulan bahan hukum dalam penelitian penulis ini adalah yang diperoleh dengan cara membaca bahan-bahan dari kepustakaan atau buku-buku yang berkaitan dengan topik masalah yang tengah diteliti oleh penulis saat ini. Dalam hal ini juga bahanbahan yang berkaitan tersebut adalah yang berkaitan dengan calon legislatif mantan narapidana dan peraturan pelaksanaan lainnya yang berlaku saat ini dan tidak merupakan peraturan yang tidak dipergunakan lagi namun memang masih berlaku.

\subsection{Analisis Badan Hukum}

Dalam menganalisis bahan hukum, penulis melakukam penelitian normatif secara kualitatif yaitu yang memang menganalisis permasalahan-permasalahan hukum yang terjadi. Pada tahap awal yang perlu dilakukan penulis adalah dengan mengumpulkan bahan primer dan sekunder, lalu kemudian bahan-bahan tersebut dikelompokkan sesuai dengan rumusan masalah yang diketengahkan penulis sebelumnya. Setelah itu, bahan-bahan hukum tersebut nanti akan dianalisis dengan melakukan interprestasi.

\section{HASIL dan PEMBAHASAN}

\subsection{Perspektif Hak Asasi Manusia Calon Legislatif Dalam} Penyelenggara Pemilu

kegiatan pemilihan umum ataupun pilkada merupakan suatu cara penyaluran hak asasi manusia yang sangat prinsipil yaitu hak untuk memilih dan dipilih dan sama kedudukannya di depan hukum sebagai warga negara dan memang merupakan hak konstitusionalnya. Sebagaimana telah dicantumkan dalam pasal 28 D UUD NKRI 1945 yang berbunyi bahwa, "setiap warga Negara berhak memperoleh kesempatan yang sama dalam pemerintahan" yang artinya negara telah memberikan kepastian hukum terhadap setiap warga negaranya untuk mendapatkan kesempatan yang sama baik itu sebagai calon wakil rakyat ataupun sebagai calon pemimpin negeri ini.

Tujuan dari pemilihan umum aadalah supaya menerapkan adanya prinsipprinsip demokrasi yang dengan cara memilih wakil rakyat di badan legislatif atau memilih kepala daerah di bidang eksekutif secara bebas dan jujur. Pelaksanaan demokrasi melalui pemilu dan pemilukada diharapkan berlangsung secara sehat jujur, adil dan demokratis sesuai dengan perundang- undangan yang telah ditetapkan sehingga memang pemilihan umum secara demokrasi tersebut memang menciptakan pemimpin-pemimpin yamg memang diharapkan oleh rakyat (Ahmad Zazili, 137).

1. larangan bagi mantan narapidana korupsi mendaftarkan diri sebagai calon legislatif

a. Sebuah Tinjauan Hak Asasi Manusia Jaminan Atas Hak Asasi Manusia (HAM) wajib dimuat Dalam UndangUndang Dasar (UUD 1945) Atau 
Konstitusi tertulis suatu Negara, dan dianggap sebagai suatu hal yang sangat penting yang harus ada dalam sebuah konstitusi agar ada kepastian hukum bagi setiap warga negara (Jimly Asshidiqie, 2011 : 243). Hak asasi manusia merupakan hak-hak dasar atau hak yang sangat mendasar yang dimiliki manusia sejak lahir bahkan sejak ia didalam kandungan dia telah memiliki hak tersebut (Mexsasai Indra, 2011 : 167). Dalam ketentuan pasal 1 angka 1 undang-undang no 39 tahun 1999 tentang hak asasi manusia dijelaskan bahwa hak asasi manusia adalah hak yang sudah melekat pada hakekat dan keberadaan manusia sebagai makhluk tuhan yang maha esa dan merupakan suatu anugerahnya yang wajib dihormati oleh manusia lainnya, dijunjung tinggi dan dilindungi oleh Negara, hukum, pemerintah, dan setiap orang demi kemormatan serta perlindungan harkat dan pemerintah dan martabat manusia.

Adapun pengelompokkan hak asasi manusia adalah sebagai berikut :

a. Kelompok pertama, yaitu kelompok yang menyangkut hak-hak sipil antara lain:

1. Hak untuk hidup. Artinya bahwa setiap orang berhak untuk mempertahankan hidup dan kehidupannya;

2. Hak untuk bebas dari penyiksaan. Artinya perlakuan dan penghukuman lain yang kejam, tidak manusiawi dan merendahkan martabat kemanusian yang artinya bahwa tidak boleh sembarangan dilakukannya penyiksaan tanpa kesalahan dan sekalipun bersalah hukumannya memang sesua dengan yang dilakukannya;

3. Hak untuk bebas dari segala perbudakan. Artinya bahwa setiap warga negara tidak boleh diperbudak oleh negaranya sendiri ataupun negara lain karena telah dijamin dalam hal ini.

b. Kelompok kedua adalah hak-hak politik, ekonomi sosial, dan budaya antara lain adalah sebagai berikut:

1. Hak untuk berserikat, berkumpul, menyatakan pendapat secara damai dengan lisan maupun tulisan yang artinya bahwa setiap orang atau kelompok bebas menyatakan aspirasinya tanpa didiskriminnasikan.

2. Hak untuk memilih dan dipilih dalam perwakilan rakyat yang artinya bahwa setiap orang dapt mencalonkan diri sebagai wakil rakyat atau pemimpin negeri ini ataupun memlih wakil dan pemimpin negeri ini.

3. Hak untuk diangkat untuk menduduki jabatan-jabatan publik yang artinya bahwa ketika dia telah dipilih dan menaang maka dia berhak menduduki jabatan publik.

4. Hak untuk memiliki hak milik pribadi yang artinya bahwa setiap orang berhak memiliki segala hal yang memang tidak bertentangan dimata hukum.

c. Kelompok ketiga, adalah kelompok hak - hak khusus dan hak atas pembangunan antara lain adalah sebagai berikut:

1. Hak perempuan dijamin dan di lindungi untuk mendapat keseteraan gender dalam kehidupan nasional yang artinya perempun mendapatkan perlakukan yang sama seperti laki-laki dalam kehidupan nasional;

2. Hak khusus yang melekat pada diri perempuan karena fungsi reproduksinya dijamin dan dilindungi hukum yang artinya bahwa perempuan diberikan hak- 
hak khusus yang memang diperlukan perempuan;

3. Hak atas lingkungan hidup yang bersih dan sehat yang artinya bahwa setiap warga negara berhak mendapatkan lingkungan yang bersih dan sehat (Jimly Assidiqie, 2012 :364)

d. Kelompok keempat, adalah kelompok yang mengatur mengenai tanggung jawab negara serta kewajiban negara dalam menjamin hak asasi manusia seperti dibawah ini sebagai berikut:

1. Setiap orang wajib menghormati hak asasi manusia dalam hal ketertiban umum, yang artinya bahwa setiap orang berkewajiban menghormati hak orang lain;

2. Setiap orang wajib tunduk pada pembatasan yang ditetapkan oleh undang-undang dengan maksud semata-mata untuk menjamin pengakuan dan penghormatan atas hak dan kebebasan orang lain serta untuk memenuhi tuntutan keadilan sesuai dengan nilai-nilai agama, moralitas, dan kesusilaan, keamanan dan ketertiban umum yang artinya bahwa warga negara pun harus tunduk kepada peraturanperaturan yang ada dan tidak boleh melanggarnya;

3. Negara berkewajiban untuk melindungi, memajukan, menegakan, dan memenuhi hakhak manusia sebagaimana tercantum dalam pembukaan UUD 1945 yang artinya bahwa negara wajib dalam hal tersebut;

4. Dalam menjamin hak asasi manusia dibentuk Komisi Nasional Hak Asasi Manusia yang bersifat independensi yang artinya bahwa adalah lembaga khusus yang menangani HAM;

e. Dari keempat kelompok hak asasi manusia tersebut terdapat hak asasi manusia yang tidak dapat dikurangi dalam keadaan apapun atau nonderorable rights, yaitu :

1. Hak untuk hidup;

2. Hak untuk tidak disiksa;

3. Hak kemerdekaan pikiran dan hati nurani;

4. Hak beragama;

5. Hak untuk diperbudak;

6. Hak untuk diakui sebagai pribadi di hadapan hukum; dan

7. Hak untuk tidak dituntut atas dasar hukum yang berlaku surut karna memang itu merupakan hak-hak dasar yang dimiliki oleh setiap warga negara yang tidak boleh dikecualikan oleh negara ( Jimly Assidiqie, 2012 : 362).

3.2. Komparasi Pengaturan Hukum Calon Legislatif Mantan Narapidana Ditinjau Dari UndangUndang Nomor 7 Tahun 2017 Tentang Pemilihan Umum Dengan Peraturan Komisi Pemilihan Umum Nomor 20 Tahun 2018 Tentang Pencalonan Anggota Dewan Perwakilan Daerah, Dewan Perwakilan Daerah Provinsi, Dewan Perwakilan Daerah, Dewan Perwakilan Daerah Provinsi, Dewan Perwakilan Kabupaten/Kota.

Komisi pemilihan umum (KPU) telah menerbitkan peraturan KPU (PKPU) Nomor 20 Tahun 2018 tentang Pencalonan Anggota DPR, DPRD Provinsi, dan DPRD Kabupaten / Kota dalam Pemilu 2019. PKPU ini akan menjadi pedoman bagi KPU dalam melaksanakan pencalonan anggota DPR, DPRD Provinsi, dan DPRD Kabupaten / Kota pemilu . Salah satu poin 
PKPU itu mengatur mengenai larangan mantan narapidana korupsi maju sebagai calon legislatif. Aturan mengenai tersebut terdapat pada Pasal yang 7 ayat (1) huruf h, yang mana berbunyi bahwa "Bukan mantan narapidana bandar narkoba, kejahatan seksual terhadap anak, atau korupsi”.

KPU sebagai penyelenggara dan pelaksanan pemilu menjadikan UndangUndang Nomor 28 Tahun 1999 sebagai bahan acuan untuk menyusun laranganlarangan bagi mantan narapidana korupsi mendaftar sebagai calon anggota legislatif. Undang-Undang tersebut mengatur mengenai tentang penyelenggaraan Negara yang bersih dan bebas dari korupsi, kolusi dan nepotisme yang merupakan unsurunsur yang merugikan negara. UndangUndang Nomor 28 Tahun 1999 tentang penyelenggaraan Negara yang bersih dan bebas dari korupsi, kolusi, dan nepotisme di dalam pasal 5 disebutkan bahwa setiap penyelenggara Negara berkewajiban untuk:

1) Mengucapkan sumpah atau janji sesuai dengan agamanya sebelum memangku jabatannya. artinya bahwa seorang yang sudah sah dan dipih sebagai wakil rakyat ataupun pemimpin negeri harus mengucapkan sumpah jabatan yang sesuai dengan agama yang dianutnya;

2) Bersedia diperiksa kekayaannya sebelum, selama, dan setelah menjabat yang artinya bahwa kekayaannya yang sebelumnya diaudit oleh pihak berwenang seperti KPK atau pihak yang berwajib untuk mengaudit harta kekayaannya;

3) Melaporkan dan mengumumkan kekayaan sebelum dan setelah menjabat yang artinya bahwa semua harta kekayaan selama ini atau sebelumnya harus di laporkan kepada pihak yang berwenang;

4) Tidak melakukan perbuatan korupsi, kolusi, dan nepotisme yang artinya bahwa segala hal yang merugikan negara tidak boleh dilakukan olehnya karena itu melanggar peraturan yang telah ada;

5) Melaksanakan tugas tanpa membedabedakan suku, agama, ras dan golongan yang artinya bahwa tidak boleh adanya diskriminasi;

6) Melaksanakan semua tugas dengan penuh rasa tanggungjawab dan tidak melakukan perbuatan tercela, tanpa pamrih baik untuk kepentingan pribadi, keluarga, kroni, maupun kelompok, dan tidak mengharapkan imbalan dalam bentuk apapun yang bertentangan dengan ketentuan peraturan perundangundangan yang berlaku yang artinya bahwa semua mereka yang telah dipih melalui pemilu dan pilkada harus melaksanakan tugas dengan penuh rasa tanggungjawab karena memang itu merupakan kewajibannya; dan

7) Bersedia menjadi saksi dalam perkara korupsi, kolusi, dan nepotisme serta dalam perkara lainnya sesuai dengan ketentuan peraturan perundangundangan yang berlaku yang artinya bahwa siap meluangkan waktu dan energinya untuk menjadi saksi dalam kasus yang merugikan negara dan sukarela.

Di dalam undang-undang tersebut mengatur sejumlah kewajiban bagi para penyelenggara Negara, yaitu dalam pasalnya yang ke 5 angka ke 4 yang berbunyi bahwa, "setiap penyelenggara Negara berkewajiban untuk tidak melakukan perbuatan korupsi, kolusi, dan nepotisme" yang artinya bahwa harus bebas dari ketiga unsur tersebut. Pemilihan anggota DPR, DPRD provinsi dan DPRD kabupaten/kota adalah orang-orang yang bersih. Aturan larangan calon anggota legislatif dari mantan narapidana korupsi merupakan bentuk perluawsasn penafsiran dari UU pemilu yaitu Undang-Undang Nomor 7 Tahun 2017. Memperluas yang 
dimaksud yaitu khususnya adalah memperluas tafsiran pasal 240 ayat (1) huruf g UU Pemilu Nomor 7 Tahun 2017, yang berbunyi; (1) Bakal calon anggota DPR, DPRD Provinsi, dan DPRD Kabupaten/Kota adalah warga Negara Indonesia dan harus memenuhi persyaratan tidak pernah dipidana penjara berdasarkan putusan pengadilan yang telah memperoleh kekuatan hukum tetap karena melakukan tidak pidana penjara 5 (lima) tahun atau lebih, kecuali secara terbuka dan jujur mengemukakan kepada public bahwa yang bersangkutan mantan pidana.

Pemerintah, Bawaslu, dan DPR melarang aturan yang dikeluarkan oleh KPU mengenai mantan narapidana korupsi untuk menjadi calon legislatif. Penilakan tersebut terjadi karena adanya dugaan KPU melarang Undang-Undang Nomor 7 tahun 2017 tentang Pemilu. Dalam UndangUndang tersebut, mantan narapidana yang sudah manjalani masa hukuman 5 tahun atau lebih boleh mencalonkan diri sebagai anggota legislatif selama yang bersangkutan mengumumkan diri ke public mengenai kasusu hukum yang pernah menjeratnya. Mereka tak boleh mencalonkan diri sebagia calon anggota legislatif sebab korupsi masuk dalam kejahatan luar biasa.

Hukum positif hingga kini tidak melarang mantan narapidana mencalonkan diri dalam pemilihan legislatif dan hanya pengadilanlah yang mempunyai kewenangan untuk mencabut hak politik seseorang. Namun memperluas tafsir undang-undang diperlukan karena korupsi adalah termasuk ke dalam kejahatan yangluar biasa. KPU mempunyai wewenang penuh menyusun auran ini. Sebab, merujuk pada putusan MK Nomor 92/PPU-XIV/2016, KPU merupakan lembaga independen. Undang-Undang Nomor 7 tahun 2017 tentang penyelenggaraan pemilu memang pada dasarnya tidak melarang mantan narapidana mencalonkan diri dalam pemilu.

Mantan narapidana kasus korupsi mempunyai hak politik, sama dengan warga Negara yang lain, suatu hak yang dijamin oleh konsitusi. Namun hal tersebut berlawanan dengan PKPU Nomor 20 Tahun 2018 tentang Pencalonan anggota DPR, DPRD Provinsi dan DPRD Kabupaten atau kota yang melarang para mantan narapidana korupsi memdaftar di pemilihan legislatif 2019. Anggota legislatif yang pernah terjerat kasus pidana tidak layak menjadi wakil rakyat. Siapa pun yang sudah pernah terjerat kasus pidana tidak layak menjadi wakil rakyat. Siapapun yang sudah pernah melakukan pidana sebaiknya tidak menjadi mewakili masyarakat. Dibutuhkan standart dalam persyaratan pencalonan legislative di Negara Indonesia, bahkan kita ketahui dalamhal persyaratan pencalonan legislatif di Negara Indonesia, bahkan kita ketahui dalam hal masyarakat yang ingi melamar pekerjaan pun menyertakan Surat Keterangan Catatan Kepolisian (SKCK). Hal tersebut bertujuan untuk mengetahui apakah orang tersebut pernah melakukan pidana. Apabila orang tersebut pernah melakukan tindak pidana, konsekuensinya adalah orang tersebut tidak akan terpilih.

PKPU dapat memperlihatkan salah satu kegunaan surat catatan kepolisisan dalam menyaring calon legislatif agar masyarakat hanya mendapatkan caleg yang terbaik. Sehingga PU akhirnya memberlakukan PKPU larangan mantan terpidana korupsi untuk maju dalam pemilihan legislatif 2019.

\section{KESIMPULAN dan SARAN}

\subsection{Kesimpulan}

a. Dalam perspektif Hak Asasi Manusia (HAM) Calon Legislatif atau wakil rakyat dalam Penyelenggaraan Pemilu secara 
umum dan langsung Hak politik warga negara mencakup hak untuk memilih dan dipilih yang artinya bahwa ada kepastian hukum bagi setiap warga negara ketika memilih wakil rakyat atau pemimpin negeri dan punya hak untuk dipih sebagai wakil rakyat ataupun pemimpin negeri ini. Penjaminan hak-hak tersebut telah tertuang dalam UUD 1945 mulai dari Pasalnya yang ke 27 ayat (1) dan (2); Pasalnya yang ke 28, Pasalnya yang ke 28D ayat (3); Pasalnya yang ke 28E ayat (3). Sementara itu hak-hak dqalam memilih juga diatur dalam Pasalnya yang ke 1 ayat (2); Pasalnya yang ke 2 ayat (1); Pasalnya yang ke 6A ayat (1); Pasalnya yang ke 19 ayat (1) dan Pasalnya yang ke 22C ayat (1) UUD 1945.

b. Komparasi Pengaturan Hukum Calon Legislatif Mantan Narapidana Ditinjau Dari UndangUndang Nomor 7 Tahun 2017 Tentang Pemilihan Umum Dengan Peraturan Komisi Pemilihan Umum Nomor 20 Tahun 2018 Tentang Pencalonan Anggota Dewan Perwakilan Daerah, Dewan Perwakilan Daerah Provinsi, Dewan Perwakilan Kabupaten/Kota. Menurut ketentuan Pasal tersebut di atas, maka PKPU dikategorikan sebagai suatu peraturan yang ditetapkan oleh komisi yang setingkat dengan lembaga negara lain yang dibentuk dengan Undang-Undang atau Pemerintah atas perintah suatu Undang-Undang. Selanjutnya, PKPU diakui keberadaannya dan mempunyai kekuatan hukum mengikat karena diperintahkan oleh peraturan perundang- undangan yang lebih tinggi dan dibentuk berdasarkan kewenangan yang diberikan Undang-Undang kepada KPU. PKPU merupakan pelaksanaan dari peraturan perundang-undangan sebagaimana yang dimaksud dalam Pasal 75 ayat (1) dan ayat (2) UndangUndang Nomor 7 Tahun 2017 tentang Pemilihan Umum yang mengatur bahwa untuk menyelenggarakan Pemilu sebagaimana diatur dalam UndangUndang ini, KPU membentuk Peraturan KPU dan Keputusan KPU.

\subsection{Saran}

1. Seharusnya semua ketentuanketentuan yang mengatur pemilu harus konsisten satu sama lain, sehingga tidak terjadi kontradiksi antar ketentuan atau antar perahiran yang ini juga berarti merupakan yang harus diperhatikan oleh si pembuat peraturan. Sehingga tidak adanya timpang tindi anra peraturan yang satu dengan peraturan yang lain supaya kepastian hukum tersebut jelas.

2. Dengan Konsistennya pengaturan hukum dalam pemilihan umum hak untuk dipilih maupun memilih maka dapat diberikan kebebasan serta kepastian hukum namun tidak melanggar suahr nortna yang lebih tinggi diatasnya. Hirarki perahrran penmdang-undangan sudah jelas dan tegas mengatur batasan masing-masing setiap kondrati dari setiap susunan perundangundangan yang harus ditaati dan di patuhi serta tidak bertentangan dengan ketentuan negara hukum serta Pancasila. 


\section{DAFTAR PUSTAKA}

\section{a. buku}

Soerjono Soekanto dan Sri Mamudji, 1995,

Penelitian Hukum Normatif, Jakarta :

Rajawali Press.

Jimly Asshidiqie, 2011, Pengantar Umu

Hukum Tata Negara, Jakarta: Rajawali

Press, Mexsasai Indra, 2011, Dinamika

Hukum Tata Negara Indonesia,

Bandung: Refika Aditama.

\section{b. undang-undang}

Undang-Undang Dasar Tahun 1945.

Undang-Undang Nomor 7 Tahun 2017

Tentang Pemilihan Umum

Peraturan Komisi Pemilihan Umum

Nomor 20 Tahun 2018 Tentang

Pencalonan Anggota

Dewan Perwakilan Daerah, Dewan

Perwakilan Daerah Provinsi,

Dewan Perwakilan

Kabupaten/Kota.

Putusan Mahkamah Konstitusi Nomor 4/PUU-VI1/2009

\section{c. jurnal}

Ahmad Zazili, 2012, Pengakuan Negara Terhadap Hak-Hak Politik (Rigth to Vote), Masyarakat Adat dalam Pelaksanaan Pemilihan Umum", Jurnal Konstitusi, Vol .9 No. 1 ,

Bisarida dkk, 2012, "Komparasi Mekansime Penyelasaian Sengketa Pemilu di Beberapa Negara Penganut Paham Demokrasi", Jurnal Konstitusi, Vol. 9, Nomor 3.

Ahmad Zazili, 2012, "Pengakuan Negara Terhadap Hak-hak Politik(Rigth to Vote) Masyarakat Adat dalam Pelaksanaan Pemilihan Umum ", Jurnal Konstitusi, Vol .9 No. 1.

Suharizal, 2010, "Penguatan Demokrasi Lokal Melalui Penghapusan Jabatan Wakil Kepala Daerah", Jurnal Konstitusi, Vol. 7, No. 5.

Suharizal, 2010, "Penguatan Demokrasi Lokal Melalui Penghapusan Jabatan Wakil Kepala Daerah", Jurnal Konstitusi, Vol. 7, No. 5. 